\title{
Efficiency of CD19 chimeric antigen receptor-modified $T$ cells for treatment of B cell malignancies in phase I clinical trials: a meta-analysis
}

\author{
Tengfei Zhang ${ }^{1,2, *}$, Ling $\mathrm{Cao}^{1,3, *}$, Jing $\mathrm{Xie}^{4, *}$, Ni Shi ${ }^{5}$, Zhen Zhang ${ }^{1,3}$, Zhenzhen Luo ${ }^{1,3}$, \\ Dongli Yue ${ }^{1,3}$, Zimeng Zhang ${ }^{6}$, Liping Wang ${ }^{3}$, Weidong Han ${ }^{7}$, Zhongwei $\mathrm{Xu}^{8}$, Hu \\ Chen $^{9}$ and Yi Zhang ${ }^{1,3,10,11}$ \\ ${ }^{1}$ Biotherapy Center, the First Affiliated Hospital of Zhengzhou University, Zhengzhou, Henan, China \\ 2 Department of Hematology and Oncology, Beth Israel Deaconess Medical Center, Harvard Medical School, Boston, \\ Massachusetts, United States \\ ${ }^{3}$ Department of Oncology, the First Affiliated Hospital of Zhengzhou University, Zhengzhou, Henan, China \\ ${ }^{4}$ Center for Eye Research Australia, Royal Victorian Eye and Ear Hospital, University of Melbourne, Melbourne, Australia \\ ${ }^{5}$ Comprehensive Cancer Center, the Ohio State University, Columbus, Ohio, United States \\ ${ }^{6}$ Department of Immunology, Harvard Medical School, Boston, Massachusetts United States \\ ${ }^{7}$ Molecular \& Immunological/Bio-Therapeutic Department, Institute of Basic Medicine, Chinese PLA General Hospital, Beijing, \\ China \\ ${ }^{8}$ Department of Gastroenterology, Pennsylvania Hospital, University of Pennsylvania, Philadelphia, Pennsylvania, United \\ States \\ ${ }^{9}$ Department of Hematopoietic Stem Cell Transplantation, Affiliated Hospital to Academy of Military Medical Science, Beijing, \\ China \\ ${ }^{10}$ Engineering Key Laboratory for Cell Therapy of Henan Province, Zhengzhou, Henan, China \\ ${ }^{11}$ School of Life Sciences, Zhengzhou University, Zhengzhou, Henan, China \\ * These authors have contributed equally to this work
}

Correspondence to: Yi Zhang, email: yizhang@zzu.edu.cn

Keywords: CD19, chimeric antigen receptor, B cell malignancies, meta analysis, efficiency

Received: July 06, $2015 \quad$ Accepted: August 20, $2015 \quad$ Published: September 10, 2015

This is an open-access article distributed under the terms of the Creative Commons Attribution License, which permits unrestricted use, distribution, and reproduction in any medium, provided the original author and source are credited.

\section{ABSTRACT}

Chimeric antigen receptor (CAR) modified T cells targeted CD19 showed promising clinical outcomes in treatment of $B$ cell malignances such as chronic lymphocytic leukemia (CLL), acute lymphoblastic leukemia (ALL) and other indolent lymphomas. However, the clinical benefit varies tremendously among different trials. This meta-analysis investigated the efficacy (response rates and survival time) of CD19-CAR T cells in refractory B cell malignances in Phase I clinical trials. We searched publications between 1991 and 2014 from PubMed and Web of Science. Pooled response rates were calculated using random-effects models. Heterogeneity was investigated by subgroup analysis and meta-regression. Fourteen clinical trials including 119 patients were eligible for response rate evaluation, 62 patients in 12 clinical trials were eligible for progression-free survival analysis. The overall pooled response rate of CD19-CAR T cells was 73\% (95\% confidence interval [CI]: 46-94\%). Significant heterogeneity across estimates of response rates was observed $(p<0.001$, I2 $=88.3 \%)$. ALL patients have higher response rate $(93 \%, 95 \%$ CI: $65-100 \%)$ than CLL (62\%, 95\% CI: $27-93 \%)$ and lymphoma patients (36\%, 95\% CI: $1-83 \%)$. Metaregression analysis identified lymphodepletion and no IL-2 administrated T cells as two key factors associated with better clinical response. Lymphodepletion and higher infused CAR T cell number were associated with better prognosis. In conclusion, this meta-analysis showed a high clinical response rate of CD19-CAR T cell-based immunotherapy in treatment of refractory B cell malignancies. Lymphodepletion and increasing number of infused CD19-CAR T cells have positive correlations with the clinical efficiency, on the contrary, IL-2 administration to T cells is not recommended. 


\section{INTRODUCTION}

Immunotherapy of cancer has shown a longer time to remission and complete cures in animal studies and clinical trials [1]. Adoptive immunotherapy using chimeric antigen receptor (CAR) modified $\mathrm{T}$ cells is a promising strategy developed in recent decades. CARs are artificial engineered receptors that can target special tumor cell surface antigen, activate $\mathrm{T}$ cells and further enhance $\mathrm{T}$ cell function MHC-independently. Objective tumor responses were reported in patients with acute lymphoblastic leukemia (ALL), chronic lymphocytic leukemia (CLL), and other indolent lymphomas after infusing autologous or allogeneic $\mathrm{T}$ cells genetically modified with CD19-CARs [2-16].

CD19 is an antigen expressed restrictively to normal and malignant B cells but not to other normal myeloid, erythroid, megakaryocytic, or multilineage bone marrow progenitor cells [17]. Therefore, CD19 is an attractive target for immunotherapies against B-cell malignancies. Compared with regular chemotherapies, application of CD19-CAR T cells showed better clinical outcomes and prognosis in treating refractory B cell malignancies. A complete remission rate of $90 \%$ and sustained remissions of up to 2 years has been reported in a clinical trial about CD19-CAR T cell therapies in patients with relapsed or refractory ALL [14]. In a recent published clinical trial of CD19-CAR-T cells in treatment of CLL patients, 3 of 4 patients achieved complete remission lasted for 23 months [7]. They also reported 8 of 11 lymphoma patients achieved remission lasted for 23 months. However, the clinical benefit varies broadly among different trials. In Savoldo's study, only two lymphoma patients achieved stable disease for 3 and 10 month but followed with disease progression [13]. In Cruz's study, only half patients achieved completed response and partial response [3]. These variations among studies might due to the different execute procedures such as the design of CAR structure, methods to introduce CAR into T cells, original $\mathrm{T}$ cell sources (autologous or allogeneic), T-cell culture conditions, lymphodepletion regimen, cytokine supports for $\mathrm{T}$ cell infusion, CAR $\mathrm{T}$ cell infusion schedule and dosage of CAR T cell. However, the key factor for better efficiency still remains unclear. A systematic review has examined the efficacy of CD19-CAR T cell therapies but the result was limited because only 5 clinical trails included in this review [18]. In this meta-analysis, we aimed to investigate the efficiency of CD19-CAR T cells immunotherapy on current published Phase I clinical trials. We also explored the factors affected the efficiency of CAR T cells immunotherapy using meta-regression analysis.

\section{RESULTS}

\section{Basic information}

After duplicated literatures and meeting abstracts removed, we found 215 literatures related with CD19CAR T cell research. Two authors identified articles eligible for further review by screen tittles and abstracts. We also found the clinical trial study literatures from the reviews. Finally, we identified 14 CD19-CAR T cellbased clinical trials for further review and analysis (Figure $1)$.

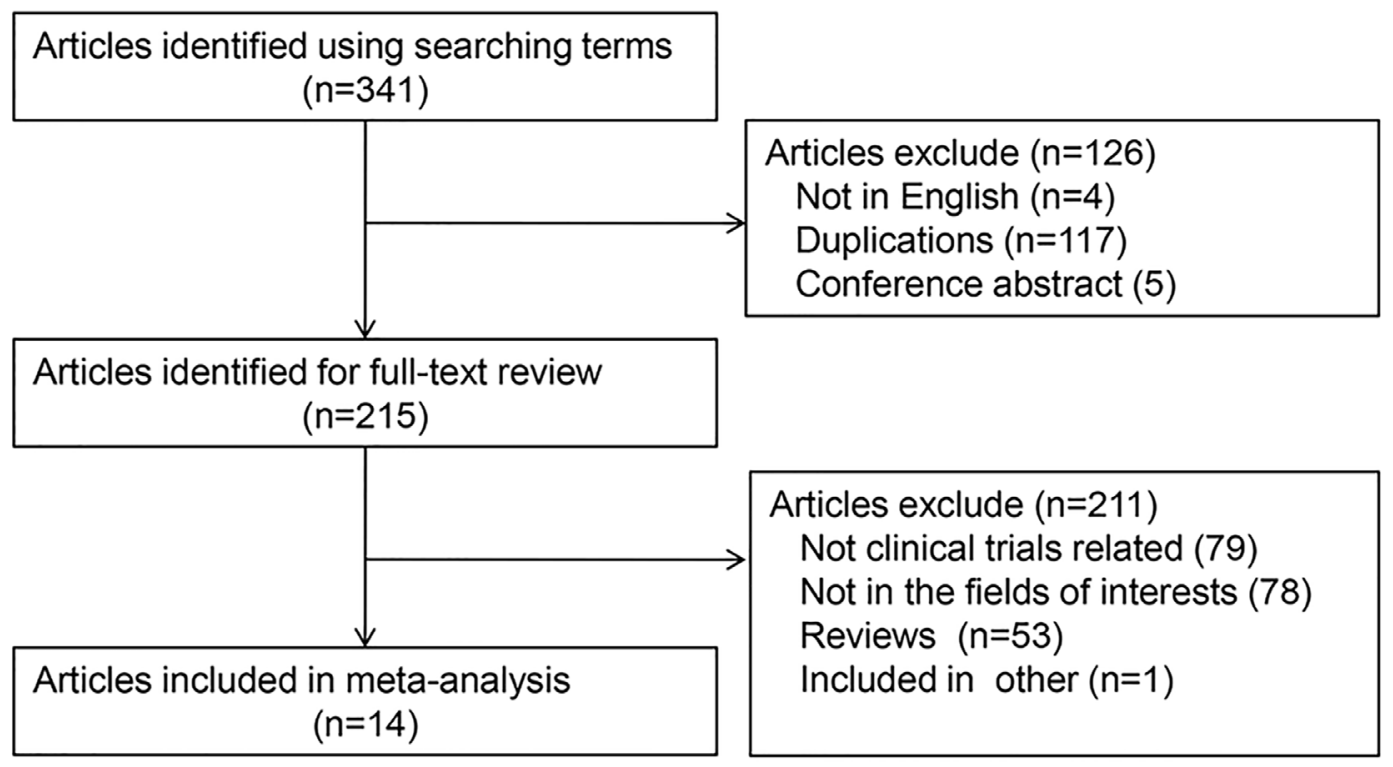

Figure 1: Flow diagram of study selection process. 
Table1: Clinical trial characteristics

\begin{tabular}{|c|c|c|c|c|c|c|c|c|c|c|c|}
\hline No. ${ }^{a}$ & Vector & $\begin{array}{c}\mathrm{T} \text { cell } \\
\text { Original }\end{array}$ & $\begin{array}{c}\text { Cell } \\
\text { culture }\end{array}$ & $\begin{array}{c}\text { Transfection } \\
\text { method }\end{array}$ & $\begin{array}{c}\text { T Cell } \\
\text { treatment }\end{array}$ & $\begin{array}{l}\text { CAR T cell } \\
\text { persistence }\end{array}$ & Diagnosis & Lymphodepletion & Dose $^{\mathrm{b}}$ & Response & Ref \\
\hline 2 & $\begin{array}{l}\text { IgG-CD4+ } \\
\text { CD3 }\end{array}$ & autologous & 3 month & Electroporation & $\begin{array}{l}\text { OKT3 + IL-2 } \\
\text { +irradiated } \\
\text { LCL feeders }\end{array}$ & 1 day & lymphoma & $\begin{array}{l}\text { Fludarabine } \\
\text { IL-2 }\end{array}$ & $10^{8}-10^{9} / \mathrm{m}^{2}$ & $2 \mathrm{PD}$ & 9 \\
\hline 1 & $\begin{array}{l}\mathrm{CD} 28+\mathrm{CD} 28 \\
\text { and } \mathrm{CD} 3\end{array}$ & autologous & $\begin{array}{l}18-26 \\
\text { day }\end{array}$ & Lentivirus & $\begin{array}{l}\text { OKT3 + IL-2 } \\
\text { +irradiated } \\
\text { LCL feeders }\end{array}$ & 36 weeks & lymphoma & $\begin{array}{l}\text { Cyclophosphamide } \\
\text { Fudarabine } \\
\text { IL-2 }\end{array}$ & $1-3 \times 10^{8}$ & PR & 12 \\
\hline 9 & $\begin{array}{l}\mathrm{CD} 28+ \\
\mathrm{CD} 28+\mathrm{CD} 3\end{array}$ & autologous & $6-18$ day & Gammaretrovirus & OKT3 + IL-2 & 5-6 weeks & $\begin{array}{l}8 \mathrm{CLL} \\
1 \mathrm{ALL}\end{array}$ & $\begin{array}{l}4 \mathrm{NA} \text {, } \\
\text { Cyclophosphamide }\end{array}$ & $0.4-3.0 \times 10^{7} / \mathrm{kg}$ & $\begin{array}{l}\text { 3NE } \mathrm{NE}^{\mathrm{c}} \text { 1Died, } \\
1 \mathrm{CR}, 1 \mathrm{PD}, \\
\text { 3SD }\end{array}$ & 10 \\
\hline 3 & $\begin{array}{l}\text { CD8-CD8 + } \\
4-1 \mathrm{BB}+\mathrm{CD} 3\end{array}$ & autologous & 10 day & Lentivirus & CD3/28 beads & 6 month & CLL & $\begin{array}{l}\text { Pentostatin } \\
\text { cyclophosphamide }\end{array}$ & $\begin{array}{l}1.46 \times 10^{5} / \mathrm{kg} \\
1.0-1.6 \times 10^{7} / \mathrm{kg}\end{array}$ & 2CR, 1PR & 6 \\
\hline 6 & $\begin{array}{l}\text { IgG-CD28+ } \\
\text { CD3/CD28- } \\
\text { CD3 }\end{array}$ & autologous & 6-8 day & Gammaretrovirus & OKT3 + IL-2 & 6 weeks & lymphoma & NA & $2-10 \times 10^{7} / \mathrm{m}^{2}$ & $6 \mathrm{PR}$ & 13 \\
\hline 8 & $\begin{array}{l}\mathrm{CD} 28+ \\
\mathrm{CD} 28+\mathrm{CD} 3\end{array}$ & autologous & 24 day & Gammaretrovirus & OKT3 + IL-2 & $\begin{array}{l}<20 \text { day or } \\
8 \text { weeks }\end{array}$ & $\begin{array}{l}\text { 4lymphoma } \\
\text { 4CLL }\end{array}$ & $\begin{array}{l}\text { Cyclophosphamide, } \\
\text { Fudarabine, } \\
\text { IL-2 }\end{array}$ & $0.3-2.8 \times 10^{7} / \mathrm{kg}$ & $\begin{array}{l}\text { 1Died, 5PR, } \\
1 \mathrm{CR}, 1 \mathrm{SD}\end{array}$ & 11 \\
\hline 5 & $\begin{array}{l}\mathrm{CD} 28+ \\
\mathrm{CD} 28+\mathrm{CD} 3\end{array}$ & autologous & 14 day & Gammaretrovirus & $\mathrm{CD} 3 / 28$ beads & 3-8 weeks & ALL & Cyclophosphamide & $1.4-3.2 \times 10^{8} / \mathrm{kg}$ & $5 \mathrm{CR}$ & 15 \\
\hline 8 & $\begin{array}{l}\text { IgG-CD28+ } \\
\text { CD28+ CD3 }\end{array}$ & allogeneic & $5-6$ week & Gammaretrovirus & $\begin{array}{l}\text { Ad. Pp65+ } \\
\text { EBV-LCLs+ } \\
\text { IL-2 }\end{array}$ & $1-12$ weeks & ALL & NA & $1.5-12 \times 10^{7} / \mathrm{m} 2$ & $\begin{array}{l}\text { 1CR, 1PR, } \\
2 \mathrm{CCR}, 1 \mathrm{SD} \\
3 \mathrm{PD}\end{array}$ & 3 \\
\hline 2 & $\begin{array}{l}\text { CD8-CD8+ 4- } \\
1 \mathrm{BB}+\mathrm{CD} 3\end{array}$ & autologous & 10 day & Lentivirus & $\mathrm{CD} 3 / 28$ beads & 6 month & ALL & $\begin{array}{l}\text { NA or } \\
\text { Cyclophosphamide }\end{array}$ & $0.14-1.2 \times 10^{7} / \mathrm{kg}$ & $2 \mathrm{CR}$ & 4 \\
\hline 10 & $\begin{array}{l}\mathrm{CD} 28+ \\
\mathrm{CD} 28+\mathrm{CD} 3\end{array}$ & allogeneic & 8 day & Gammaretrovirus & OKT3 + IL-2 & 1 month & $\begin{array}{l}4 \text { CLL } \\
6 \text { lymphoma }\end{array}$ & NA & $1 \times 10^{6} / \mathrm{kg}$ & $\begin{array}{l}\text { 6SD, 2PD, } \\
1 \mathrm{CR}, 1 \mathrm{PR}\end{array}$ & 2 \\
\hline 11 & $\lg \mathrm{G}+\mathrm{CD} 28$ & autologous & 14 day & Gammaretrovirus & $\mathrm{CD} 3 / 28$ beads & 2-3 month & ALL & Cyclophosphamide & $3 \times 10^{6} / \mathrm{kg}$ & $9 \mathrm{CR}, 2 \mathrm{NE}$ & 16 \\
\hline 15 & $\mathrm{CD} 28+\mathrm{TCR}$ & autologous & 10 day & Gammaretrovirus & OKT3 + IL-2 & $<75$ day & $\begin{array}{l}4 \text { CLL, } \\
11 \text { lymphoma }\end{array}$ & $\begin{array}{l}\text { Cyclophosphamide } \\
\text { Fudarabine }\end{array}$ & $5 \times 10^{6} / \mathrm{kg}$ & $\begin{array}{l}4 \mathrm{PR}, 8 \mathrm{CR}, \\
1 \mathrm{SD}, 2 \mathrm{NE}\end{array}$ & 7 \\
\hline 21 & $\begin{array}{l}\lg + \\
\mathrm{CD} 3+\mathrm{CD} 28\end{array}$ & autologous & 11 day & retroviruses & CD3/28 beads & 68 day & $\begin{array}{l}20 \text { ALL, } \\
1 \text { lymphoma }\end{array}$ & $\begin{array}{l}\text { Fudarabine } \\
\text { Cyclophosphamide }\end{array}$ & $1-3 \times 10^{6} / \mathrm{kg}$ & $\begin{array}{l}\text { 3SD, 4PD, } \\
13 \mathrm{CR}, \mathrm{CiR}\end{array}$ & 8 \\
\hline 30 & $\begin{array}{l}\text { CD8-CD8 + } \\
4-1 \mathrm{BB}+\mathrm{CD} 3\end{array}$ & autologous & 10 day & Lentivirus & CD3/28 beads & $\begin{array}{l}\text { up to } 11 \\
\text { month }\end{array}$ & ALL & $\begin{array}{l}\text { Fudarabine } \\
\text { Cyclophosphamide }\end{array}$ & $0.76-20 \times 10^{6} / \mathrm{kg}$ & $27 \mathrm{CR}, 3 \mathrm{NE}$ & 14 \\
\hline
\end{tabular}

\section{Clinical trial and patient clinical characteristics}

Our study included 14 Phase I clinical trials and 131 relapse or refractory B cell malignancies patients (73 ALL patients, 27 CLL patients, and 31 lymphoma patients) received CD19-CAR T cell immunotherapy [216]. The 31 lymphoma patients included 12 diffuse large B-cell lymphoma patients, 7 follicular lymphoma patients,
4 mantle cell lymphoma patients, 4 primary mediastinal B-cell lymphoma patients, 1 small lymphocytic lymphoma patients, 2 splenic marginal zone lymphoma patients and one patient without detailed subtypes. One patient died soon after infusion and another patient died because of influenza. Eight patients had no objective disease responses. Two patients lost to follow up. Therefore, 119 patients were eligible for the response rate evaluation.

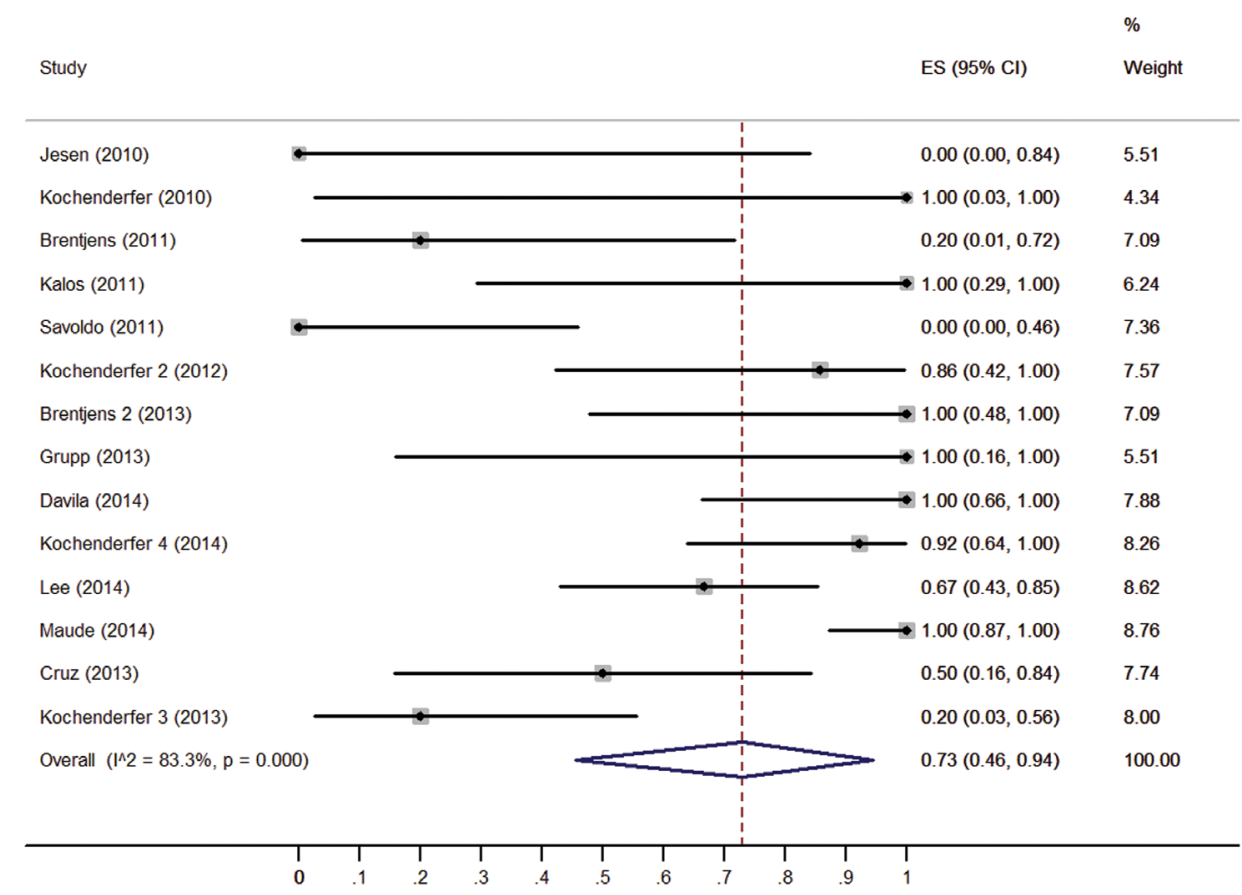

Figure 2: Forest plot for response rates and confidence intervals in each study and the overall. 
Table 2: Univariate and multivariable meta-regression analysis

\begin{tabular}{|c|c|c|c|c|c|c|}
\hline \multirow{2}{*}{$\begin{array}{l}\text { Factors at } \\
\text { study level }\end{array}$} & \multirow{2}{*}{$\begin{array}{c}\text { No. } \\
\text { of } \\
\text { Study }\end{array}$} & \multirow{2}{*}{$\begin{array}{l}\text { Response Rate } \\
(95 \% \text { CI })\end{array}$} & \multicolumn{2}{|c|}{$\begin{array}{c}\text { Univariate } \\
\text { Meta-regression analysis }\end{array}$} & \multicolumn{2}{|c|}{$\begin{array}{c}\text { Multivariable } \\
\text { Meta-regression analysis }\end{array}$} \\
\hline & & & $\begin{array}{c}\text { Coefficients } \\
(95 \% \text { CI })\end{array}$ & $\begin{array}{c}P \\
\text { value }\end{array}$ & $\begin{array}{c}\text { Coefficients } \\
(95 \% \text { CI })\end{array}$ & $\begin{array}{c}P \\
\text { value }\end{array}$ \\
\hline \multicolumn{7}{|c|}{ IL-2 administration to cell } \\
\hline Yes & 9 & $0.43(0.10,0.79)$ & 0 & \multirow[t]{2}{*}{0.002} & 0 & \multirow[t]{2}{*}{0.017} \\
\hline No & 6 & $0.98(0.81,1.00)$ & $0.437(0.164,0.710)$ & & $0.302(0.055,0.550)$ & \\
\hline \multicolumn{7}{|c|}{ IL-2 administration to patient } \\
\hline Yes & 3 & $0.64(0.00,1.00)$ & & \multirow{2}{*}{0.904} & - & \\
\hline No & 12 & $0.74(0.45,0.96)$ & $0.028(-0.434,0.491)$ & & - & \\
\hline \multicolumn{7}{|c|}{ Lymphodepletion } \\
\hline Yes & 10 & $0.88(0.65,1.00)$ & 0 & \multirow{2}{*}{0.002} & 0 & \multirow{2}{*}{0.017} \\
\hline No & 5 & $0.32(0.01,0.74)$ & $-0.415(-0.730,-0.172)$ & & $-0.347(-0.632,-0.062)$ & \\
\hline \multicolumn{7}{|l|}{ T cell origin } \\
\hline Autologous & 12 & $0.80(0.52,0.99)$ & & \multirow{2}{*}{0.054} & - & \\
\hline Allogeneic & 3 & $0.33(0.08,0.64)$ & $-0.397(-0.800,-0.007)$ & & - & \\
\hline \multicolumn{7}{|c|}{ T cell culture time } \\
\hline$\geq 2$ weeks & 7 & $0.74(0.35,0.99)$ & 0 & \multirow{2}{*}{0.834} & - & \\
\hline$<2$ weeks & 8 & $0.72(0.33,0.99)$ & $-0.037(-0.384,0.310)$ & & - & \\
\hline \multicolumn{7}{|c|}{ Total CAR T cells } \\
\hline cells $>10^{8}$ & 10 & $0.84(0.57,1.00)$ & 0 & \multirow{2}{*}{0.065} & - & \\
\hline cells $<10^{8}$ & 5 & $0.39(0.00,0.98)$ & $-0.316(-0.652,0.020)$ & & - & \\
\hline \multicolumn{7}{|c|}{ T cell persistence time } \\
\hline$\geq 2$ months & 6 & $0.99(0.80,1.00)$ & 0 & \multirow{2}{*}{0.014} & 0 & \multirow{2}{*}{0.912} \\
\hline$<2$ months & 9 & $0.48(0.15,0.82)$ & $-0.378(-0.680,-0.076)$ & & $0.014(-0.226,0.253)$ & \\
\hline
\end{tabular}

Since two of the clinical trials didn't present individual prognosis information, only 62 patients from 12 clinical trials were eligible for progression-free survival analysis.

\section{Clinical treatment strategy}

The CAR design and manufacturing process are summarized in Table 1. Among these 131 patients, 2 patients in one clinical trial were treated with Firstgeneration CAR T cells. Six patients in another clinical trial were given with both First-generation CAR T cells and Second-generation CAR $\mathrm{T}$ cells. Other patients were all administered with Second-generation CAR $\mathrm{T}$ cells. Eighteen patients in two clinical trials infused with allogeneic $\mathrm{T}$ cells derived from healthy donors, and all other patients infused with autologous $\mathrm{T}$ cells. Electroporation, lentivirus, gammaretrovirus and retroviruses are used to introduce CAR constructs into $\mathrm{T}$ cells. Most of the patients received lymphodepletion before CAR T cell infusion except 32 patients. There were 3 clinical trials didn't administrate lymphodepletion to all the patients. IL-2 was admitted to T cell culture or patients as lymphodepletion regimen. There are 72 patients without any IL-2 treatment in T cell culture or lymphodepletion regimens. The medians (range) of total infused $\mathrm{T}$ cell number and $\mathrm{CAR}^{+} \mathrm{T}$ cell number were $2.4 \times 10^{8}\left(8.76 \times 10^{6}\right.$ $\left.1.92 \times 10^{10}\right)$ and $1.5 \times 10^{8}\left(1.4 \times 10^{7}-1.1 \times 10^{10}\right)$. (Data in cells $/ \mathrm{kg}$ or cell $/ \mathrm{m}^{2}$ were multiplied by $60 \mathrm{~kg}$ or $1.73 \mathrm{~m}^{2}$ respectively.)

\section{Meta-analysis of response rate of CD19-CAR T cell in patients with refractory $B$ cell malignancies}

The response rate of CD19-CAR T cells in each clinical trial varied widely, from $0.0 \%$ [9] to $100.0 \%$ $[4,6,12,14-16]$. Figure 2 shows the overall estimate of response rate and 95\% confidence interval (CI) from the individual studies. Meta-analysis of all 14 studies yielded an overall pooled response rate of $73 \%$ (95\% CI: 46$94 \%)$, with substantial heterogeneity observed $\left(\mathrm{I}^{2}=83.3\right.$, $\left.\chi^{2}=77.63, P<0.0001\right)$. 
Table 3: Lymphodepletion as an independent factor better prognosis by Cox regression model

\begin{tabular}{|c|c|c|c|c|c|c|c|c|}
\hline \multirow{2}{*}{ Factors at study level } & \multirow{2}{*}{ B } & \multirow{2}{*}{ SE } & \multirow{2}{*}{ Wald } & \multirow{2}{*}{ df } & \multirow{2}{*}{ Sig. } & \multirow{2}{*}{$\operatorname{Exp}(B)$} & \multicolumn{2}{|c|}{ 95\% CI for $\operatorname{Exp}(B)$} \\
\hline & & & & & & & Lower & Upper \\
\hline IL-2 administration to Patient & -2.104 & 1.522 & 1.911 & 1 & 0.167 & 0.122 & 0.006 & 2.409 \\
\hline Lymphodepletion & 3.429 & 1.519 & 5.097 & 1 & 0.024 & 30.846 & 1.572 & 605.339 \\
\hline $\mathrm{T}$ cell origin & -0.986 & 1.016 & 0.943 & 1 & 0.332 & 0.373 & 0.051 & 2.730 \\
\hline $\mathrm{T}$ cell culture time & -0.673 & 1.299 & 0.268 & 1 & 0.604 & 0.510 & 0.040 & 6.507 \\
\hline Total CAR T cells & 1.333 & 0.911 & 2.140 & 1 & 0.143 & 3.793 & 0.636 & 22.629 \\
\hline $\mathrm{T}$ cell persistence time & 0.743 & 1.153 & 0.415 & 1 & 0.519 & 2.101 & 0.219 & 20.127 \\
\hline Disease Type & -0.104 & 0.744 & 0.020 & 1 & 0.889 & 0.901 & 0.210 & 3.870 \\
\hline
\end{tabular}

Note: IL-2 administration to cell was excluded from Cox regression because of the convergence.

\section{Sources of heterogeneity}

Both Begg's and Egger's regression asymmetry test showed no evidence of substantial publication bias $(P=$ 0.260 for Begg's test; $P=0.102$ for Egger's test). Then meta-regression analysis was performed based on CAR T cell protocols including $\mathrm{T}$ cell origin, $\mathrm{T}$ cell culture time, IL-2 administration to T cell culture, lymphodepletion before T cell infusion, IL-2 administration to patients, infused CAR T cell number and CAR T cell persistence time. Univariate meta-regression analysis showed that lymphodepletion, no IL-2 administration to T cells and T cell persistence more than 2 months positively associated with CD19-CAR T cells clinical responses (Table 2). Multivariable meta-regression analyses showed that lymphodepletion $(P=0.017)$ and no IL-2 administration to $\mathrm{T}$ cells $(P=0.017)$ were associated with heterogeneity.

To confirm the results of the meta-regression, subgroups were analyzed. Firstly, we compared the clinical responses among different malignancies type (ALL, CLL and lymphoma). ALL patients have higher response rate (93\%, 95\% CI: $65-100 \%)$ than CLL patients $(62 \%, 95 \%$ CI: $27-93 \%)$ and lymphoma patients $(36 \%$, 95\% CI: 1- 83\%) (Figure 3). Patients received no IL-2 administrated $\mathrm{T}$ cells had higher response rate $(98 \%, 95 \%$

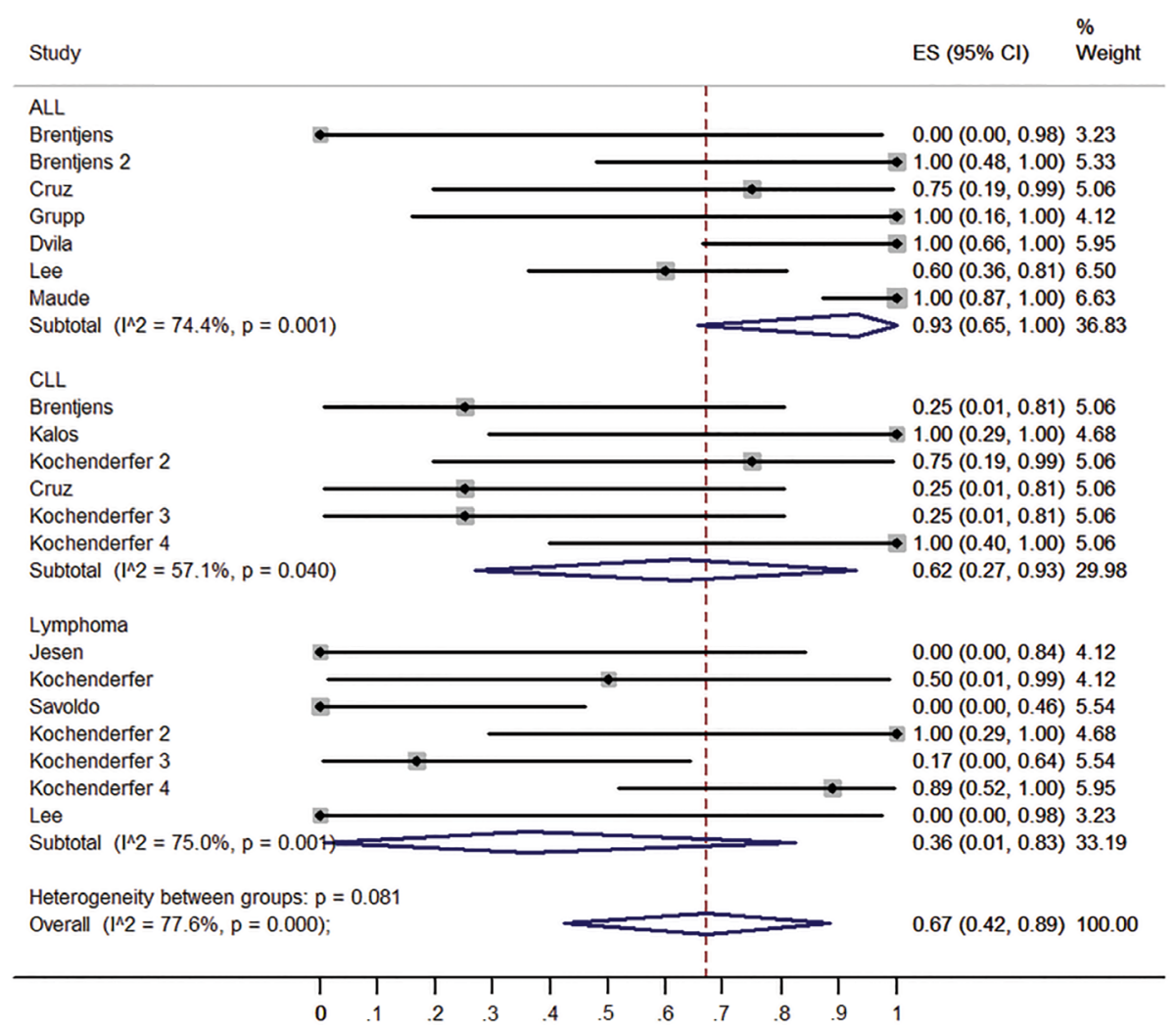

Figure 3: Forest plot for response rates and confidence internals in ALL, CLL and lymphoma patients. 


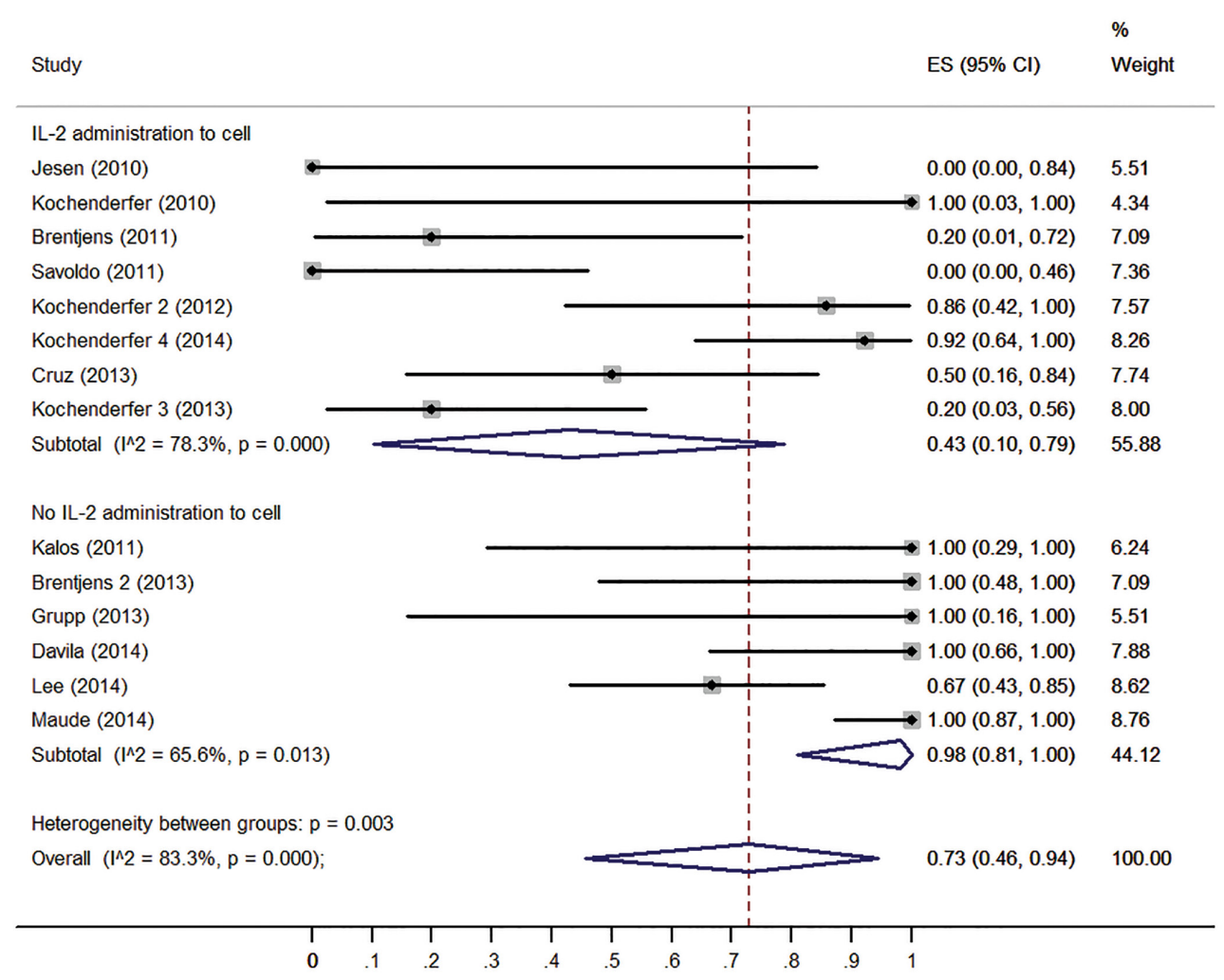

Figure 4: Forest plot for response rates and confidence internals in patients received IL-2 administrated T cells and patients received no IL-2 administrated T cells.

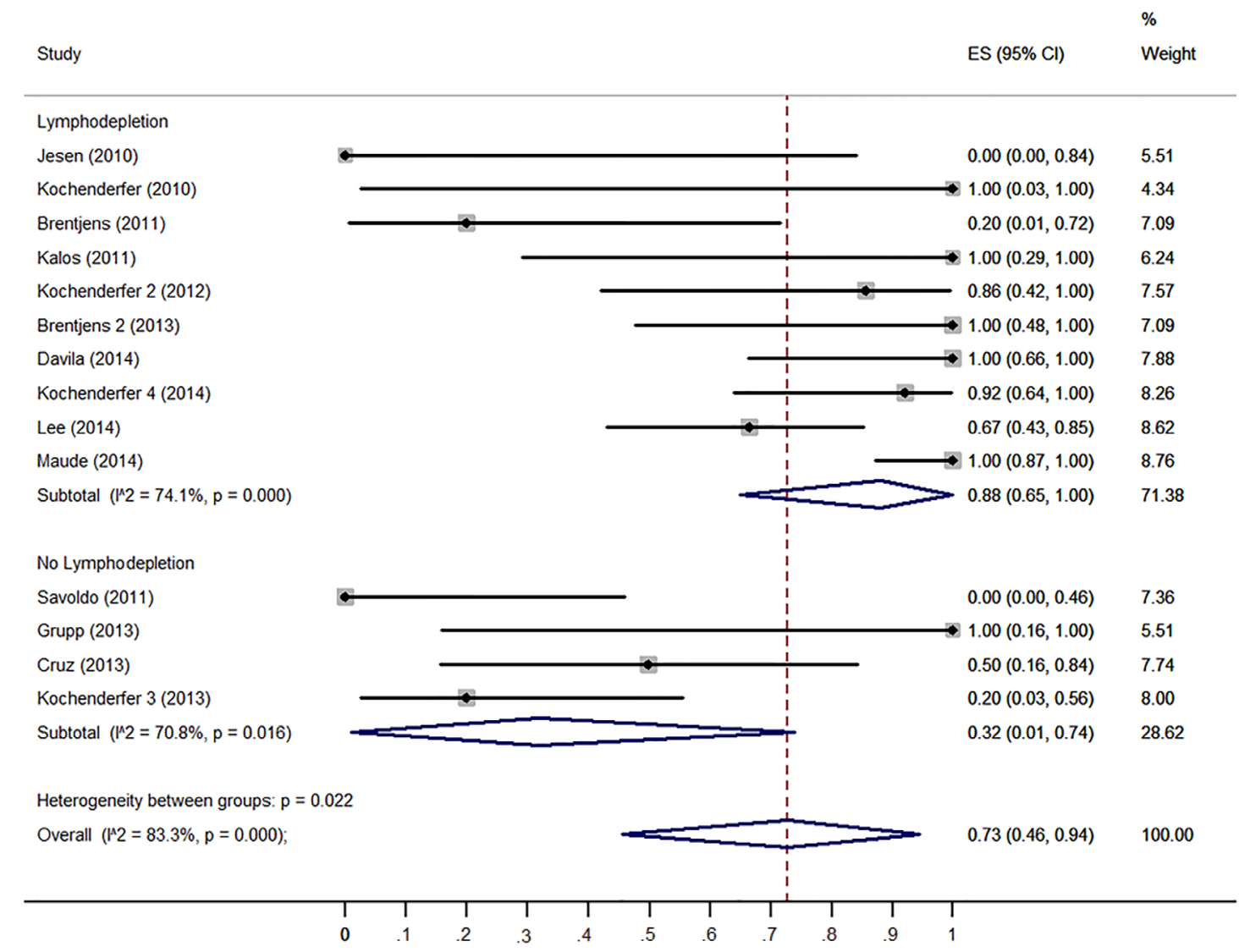

Figure 5: Forest plot for response rates and confidence internals in patients received lymphodepletion and patients without lymphodepletion. 
CI: $81-100 \%)$ than those received IL-2 administrated T cell (43\%, 95\% CI: 10-79\%) (Figure 4). Patients received lymphodepletion regimen had higher response rate $(88 \%$, $95 \%$ CI: $60-100 \%)$ than patients without lymphodepletion regimen (32\%, 95\% CI: 1-74\%) (Figure 5). Results of other non-significant difference subgroups analysis were shown in supplemental figures (Figure s1-s5) and all the detailed data were list in Supplemental Table1.

\section{Patient prognosis}

The 6-month and 1-year PFS for total 62 patients were $80.0 \%$ and $76.3 \%$ respectively (Figure 6A). The median interval of PFS was 7.0 months. Only lymphodepletion and infused $\mathrm{CAR}^{+} \mathrm{T}$ cell number were associated with better prognosis (Figure 6B, 6C). The 6-month PFS for patients administrated with lymphodepletion regimen before $\mathrm{T}$ cell infusion was $94.6 \%$, significantly higher than $54.5 \%$ in patients without lymphodepletion $(P<0.001)$. The 6-month PFS for patients infused more than $10^{8} \mathrm{CAR}^{+} \mathrm{T}$ cell was $94.4 \%$, significantly higher than $58.6 \%$ in patients infused less than $10^{8} \mathrm{CAR}^{+} \mathrm{T}$ cell $(P<0.001)$. The survival curves of other factors were list in Supplemental Figure 6 . Cox proportional hazards regression model showed that lymphodepletion was independently associated with better prognosis (Table 3).

\section{DISCUSSION}

The response rates of CD19-CAR $\mathrm{T}$ cell in refractory $\mathrm{B}$ cell malignances varied widely. In current meta-analysis, the overall pooled response rate of CD19CAR T cells in refractory B cell malignancies was 73\% (95\% CI: 46-94\%). We also showed that lymphodepletion, no IL-2 administration to T cells and T cell persistence more than 2 months positively associated with CD19-CAR $\mathrm{T}$ cells immunotherapy clinical response.

CD19-CAR T cells have shown effective outcomes in B cell malignancies. Compared with the regular chemotherapies which is lower than $40 \%$ response rate [19-21], CD19-CAR T cell immunotherapy was competitive for treatment of patients with refractory $\mathrm{B}$ cell malignancies. The response rate of CD19-CAR T cell varied in different B cell malignancies, with higher response rate in ALL than CLL or lymphomas. The lower response rate in CLL and lymphomas might due to the host T-cell defects, and the strong inhibitory effects from tumor microenvironment [1,22-25]. In two recent published clinical trials most of the ALL patients were adolescents aged less than 25 years old $[8,14]$. Compared with regular regimen for adult ALL patients, adolescents and young adults could achieve better outcome from pediatric regimen [26]. However, whether ALL patients with younger age benefit more from CD19-CAR T cell needs further investigation.

CAR T cell immunotherapy is a multiple-step clinical practice with strict quality control clinical process. Lymphodepletion was administrated before the $\mathrm{T}$ cell infusion in most of the trials. Our metaanalysis showed that patients received lymphodepletion regimen had higher response rate than patients without lymphodepletion regimen. Multivariable meta-regression analyses also showed lymphodepletion was associated with higher response rates. Moreover, the survival analysis showed that patients received lymphodepletion before $\mathrm{T}$ cell infused had better prognosis than patients without lymphodepletion $(P<0.001)$. All these results suggested that lymphodepletion was a critical factor for better clinical outcomes. Lymphodepletion before $\mathrm{T}$ cell infusion aims to remove suppressor regulatory $\mathrm{T}$ cells, eliminate some cytokines dependently lymphoid cells to extend the infused CAR T-cell persistence and expansion in vivo [18,27-28]. The meta-regression also verified $\mathrm{CAR}^{+} \mathrm{T}$ cell persistence time in vivo associated with better clinical response but not independently. Considering the response rate and microenvironments differences between ALL and CLL/lymphomas, we suggest that lymphodepletion was important for the clinical outcomes
A

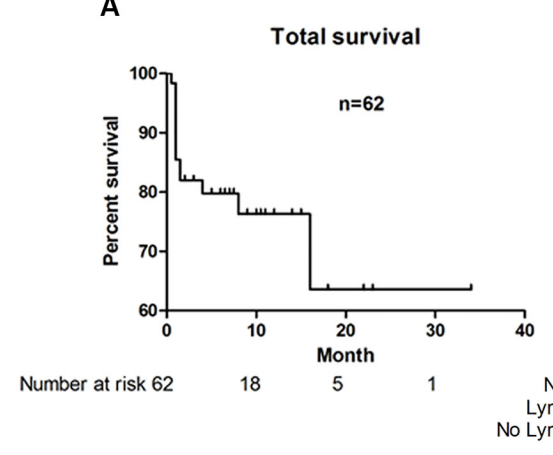

B

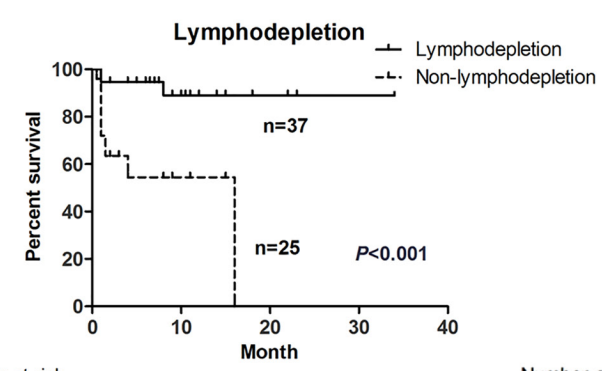

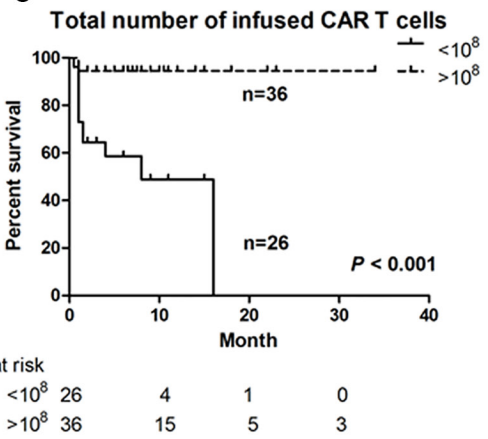

Figure 6: Progression-free survival (PFS) curves. A. the PFS for total 62 patients; B. patients benefited from lymphodepletion; C. patients benefited from more than $10^{8}$ infused total CAR T cells. 
of CAR T cells immunotherapy through regulation on tumor microenvironment. However, we didn't find any difference between the five lymphodepletion regimens by meta-regression. This may due to the small number of trials involved in the meta-analysis and too many variations in the regression setting. With more precious clinical trials about CD19-CAR T for B cell malignancies, the detailed association between lymphodepletion and clinical outcomes will be elaborated in the future.

It is recommended that cytokines can be useful in improving the expansion of First generation CAR, and potentially benefit on Second/Third generation CAR T cells. As cytokine support, IL-2 can promote T cell expansion in vitro to improve treatment outcome in CD19-CAR T cell immunotherapy [29]. But our findings showed that no IL-2 administration to T cells associated with better clinical response. Compared with Firstgeneration CARs with only a CD3 intracellular signaling domain, Second-generation CARs include another single costimulatory domain derived from either CD28 or 4-1BB [1,30]. Second-generation of CARs showed superior outcomes in both animal study and clinical trials $[1,30]$. First generation of CARs failed to elicit robust cytokine response, including IL-2 can support $\mathrm{T}$ cell expansion upon repeated exposure to antigen [30]. The key advantage of Second generation CARs was the induction of IL-2 secretion and $\mathrm{T}$ cell proliferation upon CAR cross-linking [30]. Among the fourteen trials in this Meta-analysis, thirteen clinical tirals used the Second generation CAR T cells, and part of them didn't use IL-2 during CAR T cell culture. In these clinical trials without IL-2 administration to $\mathrm{T}$ cells, anti-CD3/anti-CD28 mAb-coated magnetic beads were used to stimulate $\mathrm{T}$ cell expansion. CD28 stimulation may play a positive role for CAR $\mathrm{T}$ cell proliferation. For proliferation, CD3 antibody can provide an initial activation signal, but proliferation is dependent on co-stimulatory CD28 [31]. Both $\mathrm{CD}^{+}$and $\mathrm{CD}^{+} \mathrm{T}$ cells contribute to the in vivo expansion of $\mathrm{CAR}^{+} \mathrm{T}$ cells [13]. $\mathrm{CD}^{+} \mathrm{T}$ cells respond well to $\mathrm{CD} 3 / \mathrm{CD} 28$ stimulation. Moreover, IL-2 might limit clonally expansion and the accumulation of antigen-specific effector $\mathrm{T}$ cells by promoting activation-induced cell death [32-33], but CD3/CD28 can increase $\mathrm{T}$ cell proliferation without provoking early cell death [34]. The difference between patients received IL-2 administrated T cell and no IL-2 administration T cells may come from either IL-2 or antiCD28. However, the difference between IL-2 stimulation and CD3/CD28 stimulation still needs more verification. There was no difference between patients administrated with IL-2 or not in lymphodepletion regimen.

On-target/off-tumor effect and cytokine-released syndrome (CRS) are two major safety concerns for CAR $\mathrm{T}$ cell immunotherapy. On-target but off-tumor effects result from the immune response in normal cells with the CAR-targeted antigens. B-cell aplasia is an on-target but off-tumor effect of CD19-CAR-directed therapies
[10-11]. CRS can be caused by cytokine secretion in response to the activation of CAR T cells. CRS is often accompanied by macrophage activation syndrome, which is characteristic of hyperinflammation with prolonged fever, hepatosplenomegaly, and cytopenias [4]. Among these trials involved in this meta-analysis, the infusions were well tolerated without any immediate adverse side effects in two trials $[3,13]$. But grade 3 and grade 4 severe adverse effects associated with CD19-CAR T cell infusion were reported in all the other twelve trials, much of the toxicity that occurred in these patients was because the elevations in inflammatory cytokines. The adverse effects, fever, rigors, and dyspnea were commom within the first 24 hours, but can be controlled either by reducing the dose or between IL-6 blocker tocilizumab treatment. On-target/ off-tumor effect and B cell aplasia, was reported in six trials. However, lymphodepletion, total number of CAR $\mathrm{T}$ cells and $\mathrm{T}$ cell persistence might also correlate with the toxicities, but in this study we didn't evaluated the potential factors associated with toxicities.

To improve efficiency and reduce the toxicities, several new strategies are recruited for CAR $\mathrm{T}$ vectors. Inducible Caspase 9 (iCasp9) was integrated to CAR construction as "safety switch" to control the on-target/ off-tumor toxicities [35]. The combination of CAR and a second chimeric costimulatory receptor can increase the tumor target specific and avoid side effects [36]. Modification CAR T cells to secrete IL-12 or using native virus-specific $\mathrm{T}$ cells to transducer with CAR vectors can exhibit longer persistence time of CD19-CAR T cells in microenvironment in order to enhance the efficiency [37-38]. CTLA-4 and PD-1 are two important immune checkpoints negatively regulating $\mathrm{T}$ cell activation. Blockade PD-1, PD-L1 or CTLA-4 can prolong the efficiency of activated T cell during immune reaction [3940]. Combination of CD19-CAR T cells with PD-1/PD-1 or CLTA-4 antibodies has the possibility for better clinical outcomes.

In conclusion, our meta-analysis showed a high clinical response rate of CD19-CAR T cells in refractory $B$ cell malignancies than regular chemotherapies. The meta-analysis also found lymphodepletion regimen as a key factor associated with better clinical responses. Lymphodepletion is recommended to clinical procedures in treatment of B cell malignancies using CD19-CAR T cell-based immunotherapy. We believe that combined the new technology development with the lessons from retrospective studies would lead to better clinical efficacy by applying CD19-CAR T cells in treating B cell malignancies. 


\section{MATERIALS AND METHODS}

\section{Search strategy and study eligibility criteria}

We searched for articles published from Jan 1, 1991, to December 31, 2014 with key words "chimeric antigen receptor" combined by "AND" with "CD19" in both MEDLINE and Web of Science. Two authors (TF $\mathrm{Z}$ and $\mathrm{CL}$ ) identified articles eligible for further review by screening tittles and abstracts. When a study was considered relevant, the article was reviewed thoroughly. Only literatures published in English and reported clinical trials with the application of CD19-CAR T cells in treatment of refractory $\mathrm{B}$ cell malignancies including B-ALL, B-CLL and lymphoma were eligible for further review.

\section{Literature screening}

Gender, age, malignancies type, CAR design, gene transduction method, original $\mathrm{T}$ cell sources, $\mathrm{T}$ cell culture time, lymphodepletion, IL-2 administration for T cell culture and patient lymphodepletion regimen, total infused $\mathrm{CAR}^{+} \mathrm{T}$ cell number, $\mathrm{CAR}^{+} \mathrm{T}$ cell persistence time, patients' response to CAR T cells and follow-up time were all collected from each study. The primary endpoint was the response to CAR T cells immunotherapy. Response was based on the cytologic immunological test or computed tomography scans reported by each trial. Patients died not because of malignancies, lost follow-up, and with no objective disease response were excluded for analysis. Patients with response to CAR T cells immunotherapy were divided to two group: positive response group (patients achieved complete response (CR) or partial response (PR)), and negative response group (patients achieved stable disease (SD), progress disease (PD)). The response rate was calculated by the percentage of patients achieved complete response and partial response. For detailed analysis, IL-2 administration and lymphodepletion were analyzed by "Yes" and "No"; T cell origin was analyzed by "Autologous" and "Allogeneic"; T cell culture time was analyzed by " $\geq 2$ weeks" and " $<2$ weeks"; Total T cell culture time was analyzed by "cells $>$ $10^{8 \text { " }}$ and "cells $<10^{8 "}$ "; $\mathrm{T}$ cell persistence time was analyzed by " $\geq 2$ months" and " $<2$ months". We assessed studies for quality on the basis of the Cochrane Collaboration's method for non-randomized studies [41].

\section{Statistic analysis}

Metaprop is a statistical program implemented to perform meta-analyses of proportions in Stata13.0 (Stata Corp, College Station, TX) [42]. Metaprop implements procedures which are specific to binomial data allows computation of exact binomial and score test-based confidence interval. It provides appropriate methods for dealing with proportions close to 0 or $100 \%$. By using Metaprop, no studies with $0 \%$ or $100 \%$ proportions were excluded from the meta-analysis. The Freeman-Tukey double arcsine transformation was used to compute the weighted pooled response rate.

We used the Cochran's Q test to assess betweenstudy differences and the $\mathrm{I}^{2}$ statistic to quantify the proportion of observed inconsistency across study results not explained by chance. If the heterogeneity among trials were very large $\left(\mathrm{I}^{2}\right.$ statistic $\left.>75 \%\right)$, the observed difference between the response rates cannot be entirely attributed to sampling error and other factors such as differences in study population, etc. could also contribute. Thus, a random effects meta-analysis was used to pool the response rates of CD19-CAR T cells in refractory B cell malignances in Phase I clinical trials. The pooled response rate describes the mean of the distribution of the estimated response rate.

Univariate meta-regression analyses were conducted to identify clinical factors associated with response rate. Next, we performed a multivariate meta-regression analysis on the individually significant factors from the univariate analysis. Potential interaction was also tested between potential predictors.

To study possible publication bias, we evaluated Contour-enhanced funnel plots. A deficiency in the base of the funnel with asymmetry indicates the presence of possible publication bias from unpublished small studies. On a contour-enhanced funnel plot, contours of statistical significance are overlaid on the funnel plot. Publication bias was also assessed by two formal tests: Begg's adjusted-rank correlation test and Egger's regression asymmetry test.

All the factors analyzed in univariate metaregression analyses were evaluated for CD19 CAR T cell immunotherapy prognosis according to progressionfree survival (PFS). The interval for PFS was defined as the time from CAR $\mathrm{T}$ cell infusion to disease progress. PFS curve was estimated by Kaplan-Meier method and compared by log-rank test between each factors analyzed in univariate meta-regression analyses. The Cox proportional hazards regression model was used to identify independent prognostic factors. A two-sided $\mathrm{P}$ value was considered as statistically significant.

\section{GRANT SUPPORT}

This work was supported by grants from National Natural Science Foundation of China (Grant No. 812111102, 81171986 and 81271815), Research Grant from the Ministry of Public Health (No. 20110110001), the Basic and Advanced Technology Research Foundation from Science and Technology Department of Henan 
Province (Grant No. 112300410153, and 122300410155), Funds for Creative Research Team of Henan Province, Creative Research Team of Higher Education of Henan Province.

\section{CONFLICTS OF INTEREST}

The authors have declared that no conflict of interest exists.

\section{Editorial note}

This paper has been accepted based in part on peerreview conducted by another journal and the authors' response and revisions as well as expedited peer-review in Oncotarget.

\section{REFERENCES}

1. Maus MV, Grupp SA, Porter DL, June CH. Antibodymodified T cells: CARs take the front seat for hematologic malignancies. Blood. 2014;123:2625-35.

2. Kochenderfer JN, Dudley ME, Carpenter RO, Kassim SH, Rose JJ, Telford WG, Hakim FT, Halverson DC, Fowler DH, Hardy NM, Mato AR, Hickstein DD, GeaBanacloche JC, et al. Donor-derived CD19-targeted T cells cause regression of malignancy persisting after allogeneic hematopoietic stem cell transplantation. Blood. 2013;122:4129-39.

3. Cruz CR, Micklethwaite KP, Savoldo B, Ramos CA, Lam S, Ku S, Diouf O, Liu E, Barrett AJ, Ito S, Shpall EJ, Krance RA, Kamble RT, et al. Infusion of donorderived CD19-redirected virus-specific T cells for B-cell malignancies relapsed after allogeneic stem cell transplant: a phase 1 study. Blood. 2013;122:2965-73.

4. Grupp SA, Kalos M, Barrett D, Aplenc R, Porter DL, Rheingold SR, Teachey DT, Chew A, Hauck B, Wright $\mathrm{JF}$, Milone MC, Levine BL, June CH. Chimeric antigen receptor-modified $\mathrm{T}$ cells for acute lymphoid leukemia. $\mathrm{N}$ Engl J Med. 2013;368:1509-18.

5. Porter DL, Levine BL, Kalos M, Bagg A, June CH. Chimeric antigen receptor-modified $\mathrm{T}$ cells in chronic lymphoid leukemia. N Engl J Med. 2011;365:725-33.

6. Kalos M, Levine BL, Porter DL, Katz S, Grupp SA, Bagg A, June CH. T cells with chimeric antigen receptors have potent antitumor effects and can establish memory in patients with advanced leukemia. Sci Transl Med. 2011;3:95ra73.

7. Kochenderfer JN, Dudley ME, Kassim SH, Somerville RP, Carpenter RO, Stetler-stevenson M, Yang JC, Phan GQ, Hughes MS, Sherry RM, Raffeld M, Feldman S, Lu L, et al. Chemotherapy-Refractory Diffuse Large B-Cell Lymphoma and Indolent B-Cell Malignancies Can Be Effectively Treated With Autologous T Cells Expressing an Anti-CD19
Chimeric Antigen Receptor. J Clin Oncol. 2015;33:540-9.

8. Lee DW, Kochenderfer JN, Stetler-Stevenson M, Cui YK, Delbrook C, Feldman SA, Fry TJ, Orentas R, Sabatino M, Shah NN, Steinberg SM, Stroncek D, Tschernia N, et al. T cells expressing CD19 chimeric antigen receptors for acute lymphoblastic leukaemia in children and young adults: a phase 1 dose-escalation trial. Lancet. 2015;385:517-28.

9. Jensen MC, Popplewell L, Cooper LJ, DiGiusto D, Kalos M, Ostberg JR, Forman SJ. Antitransgene rejection responses contribute to attenuated persistence of adoptively transferred CD20/CD19-specific chimeric antigen receptor redirected T cells in humans. Biol Blood Marrow Transplant 2010;16:1245-56.

10. Brentjens RJ, Riviere I, Park JH, Davila ML, Wang X, Stefanski J, Taylor C, Yeh R, Bartido S, Borquez-Ojeda O, Olszewska M, Bernal Y, Pegram H, et al. Safety and persistence of adoptively transferred autologous CD19targeted $\mathrm{T}$ cells in patients with relapsed or chemotherapy refractory B-cell leukemias. Blood. 2011;118:4817-28.

11. Kochenderfer JN, Dudley ME, Feldman SA, Wilson WH, Spaner DE, Maric I, Stetler-Stevenson M, Phan GQ, Hughes MS, Sherry RM, Yang JC, Kammula US, Devillier $\mathrm{L}$, et al. B-cell depletion and remissions of malignancy along with cytokine-associated toxicity in a clinical trial of anti-CD19 chimeric-antigen-receptor-transduced T cells. Blood. 2012;119:2709-20.

12. Kochenderfer JN, Wilson WH, Janik JE, Dudley ME, Stetler-Stevenson M, Feldman SA, Maric I, Raffeld M, Nathan DA, Lanier BJ, Morgan RA, Rosenberg SA. Eradication of B-lineage cells and regression of lymphoma in a patient treated with autologous $\mathrm{T}$ cells genetically engineered to recognize CD19. Blood. 2010;116:4099-102.

13. Savoldo B, Ramos CA, Liu E, Mims MP, Keating MJ, Carrum G, Kamble RT, Bollard CM, Gee AP, Mei Z, Liu H, Grilley B, Rooney CM, et al. CD28 costimulation improves expansion and persistence of chimeric antigen receptor-modified $\mathrm{T}$ cells in lymphoma patients. J Clin Invest. 2011;121:1822-6.

14. Maude SL, Frey N, Shaw PA, Aplenc R, Barrett DM, Bunin NJ, Chew A, Gonzalez VE, Zheng Z, Lacey SF, Mahnke YD, Melenhorst JJ, Rheingold SR, et al. Chimeric Antigen Receptor T Cells for Sustained Remissions in Leukemia. New Engl J Med. 2014;371:1507-17.

15. Brentjens RJ, Davila ML, Riviere I, Park J, Wang X, Cowell LG, Bartido S, Stefanski J, Taylor C, Olszewska M, Borquez-Ojeda O, Qu J, Wasielewska T, et al. CD19targeted $\mathrm{T}$ cells rapidly induce molecular remissions in adults with chemotherapy-refractory acute lymphoblastic leukemia. Sci Transl Med. 2013;5:177ra38.

16. Davila ML, Riviere I, Wang X, Bartido S, Park J, Curran K, Chung SS, Stefanski J, Borquez-Ojeda O, Olszewska M, Qu J, Wasielewska T, He Q, et al. Efficacy and toxicity management of 19-28z CAR T cell therapy in B cell acute lymphoblastic leukemia. Sci Transl Med. 2014;6:224ra25.

17. Uckun FM, Jaszcz W, Ambrus JL, Fauci AS, Gajl-Peczalska 
K, Song CW, Wick MR, Myers DE, Waddick K, Ledbetter JA. Detailed studies on expression and function of CD19 surface determinant by using B43 monoclonal antibody and the clinical potential of anti-CD19 immunotoxins. Blood. 1988;71:13-29.

18. Xu XJ, Zhao HZ, Tang YM. Efficacy and safety of adoptive immunotherapy using anti-CD19 chimeric antigen receptor transduced T-cells: a systematic review of phase I clinical trials. Leuk Lymphoma. 2013;54:255-60.

19. Forman SJ, Rowe JM. The myth of the second remission of acute leukemia in the adult. Blood. 2013;121:1077-82.

20. Tam CS, O'Brien S, Plunkett W, Wierda W, Ferrajoli A, Wang X, Do KA, Cortes J, Khouri I, Kantarjian H, Lerner S, Keating MJ. Long-term results of first salvage treatment in CLL patients treated initially with FCR (fludarabine, cyclophosphamide, rituximab). Blood. 2014;124:3059-64.

21. Kater AP, Spiering M, Liu RD, Doreen Te Raa G, Slinger E, Tonino SH, Beckers MM, Daenen S, Doorduijn JK, Lankheet NA, Luijks DM, Eldering E, van Oers MH. Dasatinib in combination with fludarabine in patients with refractory chronic lymphocytic leukemia: a multicenter phase 2 study. Leuk Res. 2014;38:34-41.

22. Christopoulos P, Pfeifer D, Bartholome K, Follo M, Timmer J, Fisch P, Veelken H. Definition and characterization of the systemic T-cell dysregulation in untreated indolent B-cell lymphoma and very early CLL. Blood. 2011;117:3836-46.

23. Riches JC, Gribben JG. Understanding the immunodeficiency in chronic lymphocytic leukemia: potential clinical implications. Hematol Oncol Clin North Am. 2013;27:207-35.

24. Burger JA, Ghia P, Rosenwald A, Caligaris-Cappio F. The microenvironment in mature B-cell malignancies: a target for new treatment strategies. Blood. 2009;114:3367-75.

25. Herishanu Y, Perez-Galan P, Liu D, Biancotto A, Pittaluga S, Vire B, Gibellini F, Njuguna N, Lee E, Stennett L, Raghavachari N, Liu P, McCoy JP, et al. The lymph node microenvironment promotes B-cell receptor signaling, NF-kappaB activation, and tumor proliferation in chronic lymphocytic leukemia. Blood. 2011;117:563-74.

26. Stock W. Adolescents and young adults with acute lymphoblastic leukemia. Hematology Am Soc Hematol Educ Program. 2010;2010:21-9.

27. Kohn DB, Dotti G, Brentjens R, Savoldo B, Jensen M, Cooper LJ, June CH, Rosenberg S, Sadelain M, Heslop HE. CARs on track in the clinic. Mol Ther. 2011;19:432-8.

28. Cui Y, Zhang H, Meadors J, Poon R, Guimond M, Mackall CL. Harnessing the physiology of lymphopenia to support adoptive immunotherapy in lymphoreplete hosts. Blood. 2009;114:3831-40.

29. Rosenberg SA, Restifo NP, Yang JC, Morgan RA, Dudley ME. Adoptive cell transfer: a clinical path to effective cancer immunotherapy. Nat Rev Cancer. 2008;8:299-308.

30. Sadelain M, Brentjens R, Rivière I. The basic principles of chimeric antigen receptor design. Cancer Discov.
2013;3:388-98.

31. Frauwirth KA, Thompson CB. Activation and inhibition of lymphocytes by costimulation. J Clin Invest. 2002;109:2959.

32. Dai Z, Arakelov A, Wagener M, Konieczny BT, Lakkis FG. The role of the common cytokine receptor gamma-chain in regulating IL-2-dependent, activation-induced CD8+ T cell death. J Immunol. 1999;163:3131-7.

33. Moroz A, Eppolito C, Li Q, Tao J, Clegg CH, Shrikant PA. IL-21 enhances and sustains CD8+ T cell responses to achieve durable tumor immunity: comparative evaluation of IL-2, IL-15, and IL-21. J Immunol. 2004;173:900-9.

34. Li Y, Kurlander RJ. Comparison of anti-CD3 and antiCD28-coated beads with soluble anti-CD3 for expanding human T cells: differing impact on CD8 T cell phenotype and responsiveness to restimulation. $\mathrm{J}$ Transl Med. 2010;8:104.

35. Gargett T, Brown MP. The inducible caspase- 9 suicide gene system as a "safety switch" to limit on-target, offtumor toxicities of chimeric antigen receptor T cells. Front Pharmaco. 2014;5:235.

36. Kloss CC, Condomines M, Cartellieri M, Bachmann M, Sadelain M. Combinatorial antigen recognition with balanced signaling promotes selective tumor eradication by engineered T cells. Nat Biotechno. 2013;31:71-5.

37. Wang X, Wong CW, Urak R, Mardiros A, Budde LE, Chang WC, Thomas SH, Brown CE, La Rosa C, Diamond DJ, Jensen MC, Nakamura R, Zaia JA, et al. CMVpp65 vaccine enhances the antitumor efficacy of adoptively transferred CD19-redirected CMV-specific T cells. Clin Cancer Res. 2015; 21:2993-3002

38. Pegram HJ, Lee JC, Hayman EG, Imperato GH, Tedder TF, Sadelain M, Brentjens RJ. Tumor-targeted T cells modified to secrete IL-12 eradicate systemic tumors without need for prior conditioning. Blood. 2012;119:4133-41.

39. Chen L, Flies DB. Molecular mechanisms of $\mathrm{T}$ cell co-stimulation and co-inhibition. Nat Rev Immunol. 2013;13:227-42.

40. Pardoll DM. The blockade of immune checkpoints in cancer immunotherapy. Nat Rev Cancer. 2012;12:252-64.

41. Higgins JPT, Green S (eds). Cochrane handbook for systematic reviews of interventions, 5 th edn. The Cochrane Collaboration, 2011.

42. Victoria N, Marc A, Marc A. Metaprop: a Stata command to perform meta-analysis of binomial data. Archives of Public Health. 2014;72:39. 